\title{
Semen quality characteristics of Koekoek breeder cocks influenced by supplemental inclusion levels of onion and garlic mixture at 35-41 weeks of age
}

\author{
Victor Mela Obinna Okoro', Christian Anayochukwu Mbajiorgu', Ejikeme Felix Mbajiorgu² \\ ${ }^{1}$ University of South Africa, Department of Agriculture and Animal Health, Pretoria, South Africa. \\ ${ }^{2}$ University of Witwatersrand, Faculty of Health Sciences, School of Anatomical Sciences, Johannesburg, Gauteng, South Africa.
}

\begin{abstract}
An experiment was conducted to determine the effect of varying dietary supplemental inclusion levels of onion and garlic mixture on semen quality characteristics of Koekoek breeder cocks aged 35-41 weeks. The experimental diets were isocaloric and isonitrogenous but with different supplemental inclusion levels of onion and garlic. A complete randomized design was used for the experiment. The three dietary supplemental levels based on garlic and onion supplemental inclusion levels were $\mathrm{Q}_{0}(0 \mathrm{~g}$ onion and $0 \mathrm{~g}$ garlic per $600 \mathrm{~g}$ DM feed $), \mathrm{Q}_{1}(2.5 \mathrm{~g}$ onion and $2.5 \mathrm{~g}$ garlic per $600 \mathrm{~g} \mathrm{DM}$ feed $)$, and $\mathrm{Q}_{2}(5 \mathrm{~g}$ onion and $5 \mathrm{~g}$ garlic per $600 \mathrm{~g}$ DM feed) with each treatment having three replicates. A quadratic type equation was used to determine the onion and garlic levels for optimum semen quality characteristics. Daily supplementation with $5 \mathrm{~g}$ onion and $5 \mathrm{~g}$ garlic per $600 \mathrm{~g}$ DM feed increased progressive motile cells $(\%)$, actual life sperm count $\left(\times 10^{6} / \mathrm{nl}\right)$, and live sperm $(\%)$ by $221.20 \%, 301.51 \%$, and $352.43 \%$, while $2.5 \mathrm{~g}$ onion and $2.5 \mathrm{~g}$ garlic per $600 \mathrm{~g}$ DM feed reduced them by $28.67 \%, 12.69 \%$, and $19.00 \%$, respectively. However, daily supplementation with $2.5 \mathrm{~g}$ onion and $2.5 \mathrm{~g}$ garlic per $600 \mathrm{~g}$ DM feed increased sperm count $\left(\times 10^{6} / \mathrm{nl}\right)$ by $12.82 \%$, whereas daily supplementation with $5 \mathrm{~g}$ onion and $5 \mathrm{~g}$ garlic per $600 \mathrm{~g}$ DM feed reduced it by $10.26 \%$ in Koekoek breeder cocks. Dietary onion and garlic supplemental inclusion levels of 3.009, 3.191, 4.621, 6.601, $6.719,2.327,2.385$, and $2.247 \mathrm{~g}$ per $600 \mathrm{~g} \mathrm{DM}$ feed supported optimum progressive motile cells (\%), immotile sperm cells $(\%)$, actual dead sperm count $\left(\times 10^{6} / \mathrm{nl}\right)$, actual live sperm count $\left(\times 10^{6} / \mathrm{nl}\right)$, live sperm $(\%)$, acrosome morphology defects $(\%)$, acrosome detachment (\%), and acrosome swelling (\%), with probability values ranging from 0.003 to 0.783 , whereas minimum progressive motile cells (\%) increase was achieved at an optimum onion and garlic supplementation levels of $3.009 \mathrm{~g}$ per $600 \mathrm{~g}$ DM feed. These findings have a lot of implications on the use of supplemental onion and garlic inclusion levels to enhance reproductive efficiency in Koekoek breeder cocks.
\end{abstract}

Key Words: acrosome, dietary, function, quadractic, sperm

\section{Introduction}

One of the major issues on breeding in farm animals is infertility, and approximately $30 \%$ of the problems are related to the males (Khaki et al., 2009; Lee et al., 2012; Barkhordari et al., 2013). Recently, a wide number of plantderived pharmaceutical products are now being used in traditional medicine because of their beneficial properties in handling infertility (Yama et al., 2011). Hassanpour et al. (2011) noted that some plants such as Allium species are a rich source of a wide variety of secondary metabolites such as flavonoids, tannins, trepenoids, and alkaloids, among others. The edible Allium species - garlic (Allium sativum L.)

Received December 9, 2015 and accepted June 7, 2016

Corresponding author: melavicong@gmail.com

http://dx.doi.org/10.1590/S1806-92902016000800002

Copyright (c) 2016 Sociedade Brasileira de Zootecnia. This is an Open Access article distributed under the terms of the Creative Commons Attribution License (http://creativecommons.org/licenses/by/4.0/), which permits unrestricted use, distribution, and reproduction in any medium, provided the original work is properly cited. and onion (Allium cepa L.) - have long been used as food ingredients and medicine (Atmaca, 2003; Durrani et al., 2010; Kim et al., 2011). Khaki et al. (2009, 2012) and Alagawany et al. (2015) observed that numerous health benefits have been identified which attract researchers to investigate the validity of medical properties of these plants. They further stated that anti-oxidative properties of aqueous onion juice have been proved in studies conducted on animals, in which fresh onion juice had a positive effect on the sperm health and spermatogenesis in rats and rabbits (Khaki et al., 2012; Alagawany et al., 2015).

Over the years, maintenance of fertile cocks in most poultry breeding farms has been difficult in hot humid tropical environments. Cocks with high semen producing capacity are often few and they degenerate due to changes in factors such as age, poor nutrition, unfavorable climatic conditions, and poor management. For good results in the artificial insemination of chickens, the quality of semen should be ensured (Alkan et al., 2002). The importance of semen evaluation in poultry breeding for selection of breeding males or for routinely monitoring their reproductive 
performance is well recognized (Cheng et al., 2002). The fertilizing ability of the semen can be accessed by its motility, live/dead sperm, and morphological evaluations. The semen collector can also improve on semen quality by ensuring non-contamination of semen with faeces, urine, and or blood during semen collection at ejaculation (Alkan et al., 2002). It is therefore very important to know the proportion of abnormal spermatozoa in a semen sample in order to determine the best semen characteristics for optimum fertility (Alkan et al., 2002).

This research is aimed at identifying the effect of supplemental inclusion levels of garlic and onion on semen quality characteristics of Koekoek breeder cocks as well as identifying the optimal supplemental inclusion levels of garlic and onions as semen quality enhancers in diets for Koekoek breeder cocks aged between 35-41 weeks.

\section{Material and Methods}

This study was conducted in Owerri, Imo, Nigeria, in accordance with ethical standards and approved by the Ethics and Biosafety Committee of the University in Nigeria. The breeder cocks were obtained from Crown Feeds and Livestock Nigeria Limited (Isseleuku Delta State, Nigeria), a breeder farm that hatches and sells day-old broiler and layer chicks. Garlic and onion supplementation is a routine management practice on the farm, which is usually given to the cocks in minute quantities without gradation and fixed level of inclusion. This research was therefore aimed at subjecting this management practice to experimentation in order to ascertain the effects of garlic and onion inclusion levels on semen quality characteristics of Koekoek breeder cocks as well as determine optimum inclusion levels. A total of 27 cocks with an average body weight of $2.54 \mathrm{~kg}$, and aged 35-41 weeks (from start to end of experiment) were acquired from the breeder farm at a subsidized rate. They were assigned to three experimental groups, with each group having three replicates and three birds per replicate. Fresh Allium cepa (onion) and Allium sativum (garlic) were bought from open market at Owerri, Nigeria. The fresh A. cepa and A. sativum were then peeled, crushed, and incorporated into the test diets at the given levels of inclusion below:

$\mathrm{T}_{1}($ control $)=0 \mathrm{~g} \mathrm{~A}$. cepa $+0 \mathrm{~g}$ A. sativum $+600 \mathrm{~g}$ feed/kg DM $\left(\mathrm{Q}_{0}\right)$;

$\mathrm{T}_{2}=2.5 \mathrm{~g}$ A. cepa $+2.5 \mathrm{~g}$ A. sativum $+600 \mathrm{~g}$ feed $/ \mathrm{kg}$ $\operatorname{DM}\left(\mathrm{Q}_{1}\right)$; and

$\mathrm{T}_{3}=5 \mathrm{~g}$ A. cepa $+5 \mathrm{~g}$ A. sativum $+600 \mathrm{~g}$ feed $/ \mathrm{kg} \mathrm{DM}\left(\mathrm{Q}_{2}\right)$.

A commercial grower mash was used to feed the birds during the first week of adaptation. Thereafter, the inclusion of garlic and onion into $600 \mathrm{~g}$ of commercial grower feed (Table 1) per replicate was given to the birds. The experimental diets contained between 880 to $882 \mathrm{~g} \mathrm{DM} / \mathrm{kg}$ feed, $190 \mathrm{MJ}$ energy $/ \mathrm{kg}$ DM feed, and $220 \mathrm{~g}$ protein $/ \mathrm{kg}$ DM feed but with different supplemental inclusion levels of onion and garlic: $2.5 \mathrm{~g}$ onion and $2.5 \mathrm{~g}$ garlic per $600 \mathrm{~g}$ $\mathrm{DM}$ feed and $5 \mathrm{~g}$ onion and $5 \mathrm{~g}$ garlic per $600 \mathrm{~g}$ DM feed, respectively. Water was provided ad libitum throughout the experimental period to the animals.

Semen was collected from all the cocks in each replicate using abdominal massage technique (Lake, 1957) and evaluated for semen quality characteristics. The collection was made once every two weeks for three collections, by the abdominal massage method between $7.00 \mathrm{~h}$ and $10.00 \mathrm{~h}$ and in the months of June and July, the peak of rainy season in Nigeria. The abdominal massage techniques involved massaging the cloacal region to achieve phallic tumescence, followed by a cloacal stroke and a squeeze of the region surrounding the sides of the cloaca to express the semen. The semen was then milked down by firm finger pressure on either side of the vent into the labeled collecting tube.

Semen volume: the volume of semen was measured when it had been milked down into the graduated collecting glass test tubes. Coloured semen that was not pure white in colour was discarded, as it might have been contaminated by faeces or blood.

Semen $\mathrm{pH}$ : the $\mathrm{pH}$ of the fresh semen samples of each cockerel was measured using litmus paper (Medi-Test Combi $9^{\mathrm{TM}}$ ), by dropping the sample on the paper, and the $\mathrm{pH}$ was read.

Sperm viability (percentages of progressive, nonprogressive, and immotile sperm cells): this variable was assessed from the diluted semen (1:250) of modified Ringer's solution to a standard solution (Martin, 2004) and examined. One drop of the diluted semen was placed on the slide and covered with glass cover. Motility was estimated by microscopic observation (400 x magnification). Motility was expressed as the percentage of motile spermatozoa

Table 1 - Nutrient composition of the experimental diet

\begin{tabular}{lccc}
\hline \multirow{2}{*}{ Nutrient } & \multicolumn{3}{c}{ Diet } \\
\cline { 2 - 4 } & $\mathrm{Q}_{0}$ & $\mathrm{Q}_{1}$ & $\mathrm{Q}_{2}$ \\
\hline Dry matter $(\mathrm{g} / \mathrm{kg})$ & 882 & 881 & 880 \\
Energy $(\mathrm{MJ} / \mathrm{kg} \mathrm{DM}$ feed) & 190 & 190 & 190 \\
Crude protein $(\mathrm{g} / \mathrm{kg} \mathrm{DM})$ & 220 & 220 & 220 \\
Total G+O (g/kg DM) & 0.00 & 5 & 10 \\
Total G+O to energy ratio & 0.00 & 0.026 & 0.053 \\
Total G+O to CP ratio & 0.00 & 0.023 & 0.045 \\
\hline
\end{tabular}

$\mathrm{DM}$ - dry matter; $\mathrm{G}$ - garlic; O - onion; CP - crude protein.

$\mathrm{Q}_{0}-0 \mathrm{~g}$ onion and $0 \mathrm{~g}$ garlic per $600 \mathrm{~g}$ DM feed; $\mathrm{Q}_{1}-2.5 \mathrm{~g}$ onion and $2.5 \mathrm{~g}$ garlic per $600 \mathrm{~g}$ DM feed; and $\mathrm{Q}_{2}-5 \mathrm{~g}$ onion and $5 \mathrm{~g}$ garlic per $600 \mathrm{~g}$ DM feed. 
with moderate to rapid progressive forward movements in large circles, while non-progressive are those with low to moderate progressive, on the spot twitching movement, and immotile were non-moving spermatozoa. At least 15 microscopic fields were examined for each sample.

Sperm concentration: expressed as the number of cells per cubic centimeter of semen. The concentrations of sperm cells were determined with a hemocytometer after the semen had been diluted to a standard volume.

Sperm vitality assessment (live and dead percentage): a drop of semen was placed on a microscope slide with a micropipette, and a drop of eosin-negrosin stain was added, smeared, immediately air-dried, and viewed under a microscope at $400 \times$ magnification. The proportions of live (eosin-impermeable) and dead (eosin-permeable) spermatozoa in a sample were assessed on the basis of 300 cells counted.

Sperm vitality assessment (actual live and actual dead sperm count): estimated from the total sperm count assessed from each individual in relation to the percentage live and dead sperm count.

Sperm acrosome morphology and defects: morphology was examined in smears stained with eosin and nigrosin. At each preparation, 300 cells were counted and the percentage of various defects was calculated. Thus, the morphological defects of acrosome detachment, swelling, and abnormality were evaluated. The acrosomal morphology defects were then categorized into three classes: detached acrosome (characterized by presence of acrosome with separated head, neck, and tail); swollen acrosome (characterized by acrosome with swollen and ruffled apical ridge and neck); and acrosome abnormality (characterized by presence of acrosome with irregular shaped head).
Data generated were analyzed by one-way analysis of variance (Statistical Analysis System, version 9.2). Whenever a significance was detected by the F-test $(\mathrm{P}<0.05)$, the least significant difference (LSD) method was used to separate the means (Statistical Analysis System, version 9.2). The semen parameters significantly affected by supplemental inclusion of garlic and onions were modelled using the following quadratic model:

$$
\mathrm{Y}=\mathrm{a}+\mathrm{b}_{1} \mathrm{x}+\mathrm{b}_{2} \mathrm{x}^{2}+\mathrm{e},
$$

in which $Y=$ semen quality characteristics; $a=$ intercept on Y-axis; $b=$ coefficients of the independent variable $\mathrm{x}$, which is the inclusion ratio of onion and garlic estimated as $-b_{1} / 2 b_{2}$, which is the value of $\mathrm{x}$ that gives the optimum inclusion level. The quadratic model was fitted to the experimental data by means of the non-linear model (NLIN) procedure of SAS (Statistical Analysis System, version 9.2). The quadratic model was used because it gave the best fit.

\section{Results}

There were significant effects $(\mathrm{P}<0.05)$ of onion and garlic supplemental inclusion levels on progressive motile cells $(\%)$, immotile sperm cells $(\%)$, sperm count $\left(\times 10^{6} / \mathrm{nl}\right)$, actual dead sperm count $\left(\times 10^{6} / \mathrm{nl}\right)$, actual live sperm count $\left(\times 10^{6} / \mathrm{nl}\right)$, live sperm $(\%)$, acrosome morphology defects $(\%)$, acrosome detachment (\%) and acrosome swelling (\%), while there was no effect $(\mathrm{P}>0.05)$ on other parameters studied (Table 2). Daily supplementation with $2.5 \mathrm{~g}$ onion and $2.5 \mathrm{~g}$ garlic per $600 \mathrm{~g}$ DM feed reduced $(\mathrm{P}>0.05)$ progressive motile cells (\%) by $28.67 \%$, whereas daily supplementation with $5 \mathrm{~g}$ onion and $5 \mathrm{~g}$ garlic per $600 \mathrm{~g}$ DM feed increased it $(\mathrm{P}<0.05)$ by $221.20 \%$ in Koekoek breeder cocks (Table 3 ).

Table 2 - Effect of garlic and onion on semen characteristics of Koekoek cocks

\begin{tabular}{|c|c|c|c|c|c|}
\hline \multirow{2}{*}{ Semen characteristic } & \multicolumn{3}{|c|}{ Diet } & \multirow{2}{*}{ SE } & \multirow{2}{*}{ P-value } \\
\hline & $\mathrm{Q}_{0}$ & $\mathrm{Q}_{1}$ & $\mathrm{Q}_{2}$ & & \\
\hline Sperm volume & 0.40 & 0.50 & 0.50 & 0.058 & 0.912 \\
\hline Sperm pH & 8.00 & 8.00 & 8.00 & 0.000 & 0.988 \\
\hline Progressive motile cells (\%) & $4.67 b$ & $3.33 b$ & $15.00 \mathrm{a}$ & 2.681 & 0.015 \\
\hline Non-progressive motile cells (\%) & 2.33 & 2.33 & 6.67 & 2.886 & 0.133 \\
\hline Immotile sperm cells (\%) & $93.00 \mathrm{a}$ & $94.33 \mathrm{a}$ & $68.33 b$ & 4.895 & 0.054 \\
\hline Sperm count $\left(\times 10^{6} / \mathrm{nl}\right)$ & $65.00 \mathrm{ab}$ & $73.33 \mathrm{a}$ & $58.33 b$ & 2.722 & 0.045 \\
\hline Actual dead sperm count $\left(\times 10^{6} / \mathrm{nl}\right)$ & $48.35 \mathrm{ab}$ & $69.37 \mathrm{a}$ & $39.67 b$ & 8.336 & 0.056 \\
\hline Dead sperm count $(\%)$ & 73.00 & 94.33 & 68.33 & 11.134 & 0.786 \\
\hline Actual live sperm count $\left(\times 10^{6} / \mathrm{nl}\right)$ & $4.65 b$ & $3.97 b$ & $18.67 \mathrm{a}$ & 3.191 & 0.032 \\
\hline Live sperm (\%) & $7.00 \mathrm{~b}$ & $5.67 \mathrm{~b}$ & $31.67 \mathrm{a}$ & 4.895 & 0.018 \\
\hline \multicolumn{6}{|l|}{ Sperm morphology defects } \\
\hline Acrosome morphology defects (\%) & $81.67 \mathrm{ab}$ & $82.67 \mathrm{a}$ & $72.33 b$ & 2.769 & 0.052 \\
\hline Acrosome detachment (\%) & $76.00 \mathrm{a}$ & $72.00 \mathrm{a}$ & $60.00 \mathrm{~b}$ & 2.517 & 0.048 \\
\hline Acrosome swelling (\%) & $5.33 b$ & $8.33 \mathrm{ab}$ & $11.33 \mathrm{a}$ & 1.732 & 0.059 \\
\hline Acrosome abnormality (\%) & 0.33 & 2.33 & 1.00 & 0.638 & 0.154 \\
\hline
\end{tabular}

$\mathrm{Q}_{0}-0 \mathrm{~g}$ onion and $0 \mathrm{~g}$ garlic per $600 \mathrm{~g}$ DM feed; $\mathrm{Q}_{1}-2.5 \mathrm{~g}$ onion and $2.5 \mathrm{~g}$ garlic per $600 \mathrm{~g} \mathrm{DM}$ feed; and $\mathrm{Q}_{2}-5 \mathrm{~g}$ onion and $5 \mathrm{~g}$ garlic per $600 \mathrm{~g} \mathrm{DM}$ feed.

$\mathrm{SE}$ - standard error.

$\mathrm{a}, \mathrm{b}$ - means in the same row with different letters are significantly different $(\mathrm{P}<0.05)$. 
Similarly, daily supplementation with $2.5 \mathrm{~g}$ onion and $2.5 \mathrm{~g}$ garlic per $600 \mathrm{~g}$ DM feed increased $(\mathrm{P}>0.05)$ immotile sperm cells (\%), sperm count $\left(\times 10^{6} / \mathrm{nl}\right)$, and actual dead sperm count $\left(\times 10^{6} / \mathrm{nl}\right)$ by $1.43 \%, 12.82 \%$, and $43.47 \%$ respectively, whereas daily supplementation with $5 \mathrm{~g}$ onion and $5 \mathrm{~g}$ garlic per 600 g DM feed reduced them $(\mathrm{P}<0.05)$ by $26.53 \%$, $10.26 \%$, and $17.95 \%$, respectively in Koekoek breeder cocks (Table 3 ). Daily supplementation with $2.5 \mathrm{~g}$ onion and $2.5 \mathrm{~g}$ garlic per $600 \mathrm{~g}$ DM feed reduced non-significantly $(\mathrm{P}>0.05)$ actual life sperm count $\left(\times 10^{6} / \mathrm{nl}\right)$ and live sperm (\%) by $12.69 \%$ and $19.00 \%$, respectively, whereas daily supplementation with $5 \mathrm{~g}$ onion and $5 \mathrm{~g}$ garlic per $600 \mathrm{~g}$ DM feed increased them significantly $(\mathrm{P}<0.05)$ by $301.51 \%$ and $352.43 \%$ in Koekoek breeder cocks (Table 3).

In the same manner, effects of daily supplementation with $2.5 \mathrm{~g}$ onion and $2.5 \mathrm{~g}$ garlic per $600 \mathrm{~g}$ DM feed on sperm morphological defects increased $(\mathrm{P}>0.05)$ acrosome morphology defects (\%) by $1.22 \%$, whereas daily supplementation with $5 \mathrm{~g}$ onion and $5 \mathrm{~g}$ garlic per $600 \mathrm{~g}$ DM feed decreased it significantly $(\mathrm{P}<0.05)$ by $11.44 \%$ in Koekoek breeder cocks (Table 3). Daily supplementation with $2.5 \mathrm{~g}$ onion and $2.5 \mathrm{~g}$ garlic per $600 \mathrm{~g}$ DM feed reduced $(\mathrm{P}>0.05)$ acrosome detachment $(\%)$ by $5.26 \%$, whereas daily supplementation with $5 \mathrm{~g}$ onion and $5 \mathrm{~g}$ garlic per $600 \mathrm{~g}$ DM feed reduced it $(\mathrm{P}<0.05)$ by $21.05 \%$ in
Koekoek breeder cocks (Table 3). Daily supplementation with $2.5 \mathrm{~g}$ onion and $2.5 \mathrm{~g}$ garlic per $600 \mathrm{~g}$ DM feed increased ( $\mathrm{P}>0.05$ ) acrosome swelling (\%) by $56.29 \%$, whereas daily supplementation with $5 \mathrm{~g}$ onion and $5 \mathrm{~g}$ garlic per $600 \mathrm{~g}$ DM feed increased it $(\mathrm{P}<0.05)$ by $112.57 \%$ in Koekoek breeder cocks. Dietary onion and garlic supplemental inclusion levels of 3.009, 3.191, 4.621, 6.601, 6.719, 2.327, 2.385 , and $2.247 \mathrm{~g}$ per $600 \mathrm{~g}$ DM feed supported optimum progressive motile cells (\%), immotile sperm cells (\%), actual dead sperm count $\left(\times 10^{6} / \mathrm{nl}\right)$, actual live sperm count $\left(\times 10^{6} / \mathrm{nl}\right)$, live sperm $(\%)$, acrosome morphology defects (\%), acrosome detachment (\%), and acrosome swelling (\%), with probability values ranging from 0.003 to 0.783 , whereas minimum progressive motile cells (\%) increase was achieved at an optimum onion and garlic supplementation level of 3.009 g per $600 \mathrm{~g}$ DM feed $(\mathrm{Y}=4.333+7.300 \mathrm{x}$ $\left.-1.213 \mathrm{x}^{2} ; \mathrm{r}^{2}=0.979 ; \mathrm{P}=0.003\right)$ (Table 4).

\section{Discussion}

The semen volume and $\mathrm{pH}$ reported in this study ranged from $0.40-0.50 \mathrm{~mL}$ for semen volume and 7.088.00 for semen pH. However, Hafez and Hafez (2000) reported semen volume and $\mathrm{pH}$ ranging from $0.2-0.5 \mathrm{~mL}$, and 7.2-7.6 in domestic cockerels. This shows a little

Table 3 - Significant percentage change from control and dietary supplementation of onion and garlic inclusion levels on significant parameters in Koekoek cocks

\begin{tabular}{|c|c|c|c|c|c|c|}
\hline \multirow{3}{*}{ Significant parameter } & \multicolumn{6}{|c|}{ Percentage increase/decrease due to supplementation } \\
\hline & \multicolumn{3}{|c|}{$2.5 \mathrm{~g}$ onion and $2.5 \mathrm{~g}$ garlic $\left(\mathrm{Q}_{1}\right)$} & \multicolumn{3}{|c|}{$5 \mathrm{~g}$ onion and $5 \mathrm{~g}$ garlic $\left(\mathrm{Q}_{2}\right)$} \\
\hline & $(\%)$ & Change & Significance & $(\%)$ & Change & Significance \\
\hline Progressive motile cells (\%) & 28.67 & Decrease & ns & 221.20 & Increase & $\mathrm{s}$ \\
\hline Immotile sperm cells (\%) & 1.43 & Increase & ns & 26.53 & Decrease & $\mathrm{s}$ \\
\hline Sperm count $\left(\times 10^{6} / \mathrm{nl}\right)$ & 12.82 & Increase & ns & 10.26 & Decrease & $\mathrm{S}$ \\
\hline Actual dead sperm count $\left(\times 10^{6} / \mathrm{nl}\right)$ & 43.47 & Increase & ns & 17.95 & Decrease & $\mathrm{s}$ \\
\hline Actual live sperm count $\left(\times 10^{6} / \mathrm{nl}\right)$ & 12.69 & Decrease & ns & 301.51 & Increase & $\mathrm{s}$ \\
\hline Live sperm count $(\%)$ & 19.00 & Decrease & ns & 352.43 & Increase & $\mathrm{S}$ \\
\hline \multicolumn{7}{|l|}{ Sperm morphology defects } \\
\hline Acrosome morphology defects $(\%)$ & 1.22 & Increase & ns & 11.44 & Decrease & $\mathrm{S}$ \\
\hline Acrosome detachment (\%) & 5.26 & Decrease & ns & 21.05 & Decrease & $\mathrm{s}$ \\
\hline Acrosome swelling (\%) & 56.29 & Increase & ns & 112.57 & Increase & $\mathrm{S}$ \\
\hline
\end{tabular}

$\mathrm{S}$ - significant difference $(\mathrm{P}<0.05)$ between $\mathrm{Q}_{1}$ and $\mathrm{Q}_{2} ;$ ns - no significant difference $(\mathrm{P}>0.05)$ between $\mathrm{Q}_{1}$ and $\mathrm{Q}_{2}$.

Table 4 - Optimal inclusion of garlic $(\mathrm{G})$ and onion $(\mathrm{O})$ on sperm quality characteristics of Koekoek cocks using quadratic function

\begin{tabular}{|c|c|c|c|c|}
\hline Trait & Quadratic function & Optimal \% $\mathrm{G}+\mathrm{O}$ inclusion level & $\mathrm{R}^{2}$ value & Probability values \\
\hline Progressive motile cells & $Y=4.333+7.300 x-1.213 x^{2}$ & 3.009 & 0.979 & 0.003 \\
\hline Immotile sperm cells & $Y=90.00-4.933 x+0.773 x^{2}$ & 3.191 & 0.474 & 0.381 \\
\hline Actual dead sperm count $\left(\times 10^{6} / \mathrm{nl}\right)$ & $Y=60.03-5.683 x+0.615 x^{2}$ & 4.620 & 0.203 & 0.711 \\
\hline Actual live sperm count $\left(\times 10^{6} / \mathrm{nl}\right)$ & $Y=6.633+6.350 x-0.481 x^{2}$ & 6.601 & 0.369 & 0.501 \\
\hline Live sperm $(\%)$ & $Y=10.00+8.600 x-0.640 x^{2}$ & 6.719 & 0.346 & 0.529 \\
\hline \multicolumn{5}{|l|}{ Sperm morphology defects } \\
\hline Acrosome morphology defects $(\%)$ & $Y=74.50+4.467 x+0.960 x^{2}$ & 2.327 & 0.151 & 0.783 \\
\hline Acrosome detachment (\%) & $Y=67.167+6.167 x-1.293 x^{2}$ & 2.385 & 0.206 & 0.708 \\
\hline Acrosome swelling (\%) & $Y=5.833-1.200 x+0.267 x^{2}$ & 2.247 & 0.527 & 0.325 \\
\hline
\end{tabular}


variation which could be accounted for by the age of the cocks, being adult birds. However various factors had been reported that account for wide variations in semen quality characteristics of birds, like breed (Peters et al., 2008), strain (Murugesan et al., 2013), and line (Tarif et al., 2013). The semen quality parameters reported for different breeds like White Leghorn (Elagib et al., 2012), Plymouth Rock (Tarif et al., 2013), Rhode Island Red (RIR) (Kabir et al., 2007), and indigenous roosters (Ajayi et al., 2011) demonstrated a high degree of variation. The environmental factors having influence on semen quality are climate (Saeed and Al-Soudi, 1975), time of collection (Egbunike and Oluyemi, 1979), frequency of collection (Riaz et al., 2004), and nutrition (Kabir et al., 2007). Additionally, the high concentration of immotile sperm cells in this study ranging from $68.33-94.33 \%$ of total viable spermatozoa shows that it is very high. This could be a result of high morphological defects also recorded in this study, as Alkan et al. (2002) reported that morphological defect types of turkey and cock semen are similar and the most frequent defects are observed at the acrosome and mid-piece, suggesting that these organelles are the most susceptible to environmental factors and influence semen viability. However, the values of progressive motile cells were significant but inconsistent with the level of onion and garlic supplementation used in the present study. Also, the sperm count, which tended to lie slightly above the range of $30-70\left(\times 10^{6} / \mathrm{nl}\right)$ as reported by Hafez and Hafez (2000), is significantly influenced by increased inclusion of onion and garlic. According to this study, increased inclusion of $5 \mathrm{~g}$ onion and $5 \mathrm{~g}$ garlic optimized progressive motile cells, while $2.5 \mathrm{~g}$ onion and 2.5 g garlic optimized sperm count, which implies that different semen characteristics are influenced differently at different inclusion levels of onion and garlic.

Results from the present study indicate that there was a significant effect $(\mathrm{P}<0.05)$ of onion and garlic supplemental inclusion levels on progressive motile cells (\%), immotile sperm cells $(\%)$, sperm count $\left(\times 10^{6} / \mathrm{nl}\right)$, actual dead sperm count $\left(\times 10^{6} / \mathrm{nl}\right)$, actual live sperm count $\left(\times 10^{6} / \mathrm{nl}\right)$, live sperm (\%), acrosome morphology defects (\%), acrosome detachment (\%), and acrosome swelling (\%). These findings suggest that these sperm reproductive parameters are first and foremost influenced by the range of onion and garlic supplemental inclusion levels used in the present study and hence, these parameters attempt, as a priority, to respond and adjust to the onion and garlic supplemental levels. This is confirmed by the obtained results, in which daily supplementation with $5 \mathrm{~g}$ onion and $5 \mathrm{~g}$ garlic per $600 \mathrm{~g}$ DM feed increased $(\mathrm{P}<0.05)$ progressive motile cells $(\%)$, actual life sperm count $\left(\times 10^{6} / \mathrm{nl}\right)$, and live sperm $(\%)$ by
$221.20 \%, 301.51 \%$, and $352.43 \%$ from the control result, while $2.5 \mathrm{~g}$ onion and $2.5 \mathrm{~g}$ garlic per $600 \mathrm{~g}$ DM feed reduced them $(\mathrm{P}>0.05)$ by $28.67 \%, 12.69 \%$, and $19.00 \%$, respectively (Table 3). Meanwhile, supplementation with $5 \mathrm{~g}$ onion and $5 \mathrm{~g}$ garlic per $600 \mathrm{~g}$ DM feed reduced $(\mathrm{P}<0.05)$ sperm count $\left(\times 10^{6} / \mathrm{nl}\right)$ and actual dead sperm count $\left(\times 10^{6} / \mathrm{nl}\right)$ by $10.26 \%$ and $17.95 \%$, while $2.5 \mathrm{~g}$ onion and $2.5 \mathrm{~g}$ garlic per $600 \mathrm{~g}$ DM feed increased $(\mathrm{P}>0.05)$ them by $12.82 \%$ and $43.47 \%$, respectively, in Koekoek breeder cocks. Thus, one possible consequence of these responses to dietary supplemental onion and garlic inclusion levels might be the gain of sensitivity to regulate sperm parametric characteristics according to onion and garlic supplemental inclusion levels as observed in the present study. The physiological explanation for the present observation is not clear and merits further observation. However, it is known that some researchers have shown that onion contains exogenous and endogenous antioxidants such as selenium, glutathione, vitamins $\mathrm{A}, \mathrm{B}$, and $\mathrm{C}$ and flavonoids such as quercetin and isorhamnetin (Griffiths et al., 2002). These antioxidants protect DNA and other important molecules from oxidation and damage, which would otherwise induce apoptosis, and could improve sperm health parameters, increasing the rate of fertility in men (Hunt et al., 1992; Izawa et al., 2008). Khaki et al. (2008) also demonstrated that the administration of onion juice ( $1 \mathrm{~g} / \mathrm{rat} /$ day) for 20 days increases sperm count, viability, and motility in rats. The onion fresh juice can significantly increase the recovery of sperm health parameters such as count, motility, and serum total testosterone and total antioxidants capacity (Chakrabarti et al., 2003) levels in T. gondii- infected rats (Khaki et al., 2011). On the other hand, garlic has been used as medicine worldwide since ancient times (Arzanlou and Bohlooli, 2010). It contains a wide variety of phytochemicals and micro components such as trace elements, vitamins, fructans, flavonoids, and sulphur compounds which can scavenge free radicals (Khaki et al., 2011). Therefore, importantly, one possible consequence of these ad libitum combinations of onion and garlic in the diet of Koekoek breeder cocks might be the pulling together of these qualities, which invariably influenced and improved the sperm health parameters of the birds as well as their semen viability, as observed in this study. Therefore, it appears from the result obtained herein that birds would likely benefit practically from ad libitum supplemental combination of onion and garlic in terms of enhancing their sperm health parameters and as such help to improve their reproductive efficiency.

Also, results of the present study indicate that dietary onion and garlic supplemental inclusion levels of 3.009, $3.191,4.621,6.601,6.719,2.327,2.385$, and $2.247 \mathrm{~g}$ per 
$600 \mathrm{~g}$ DM feed supported optimum progressive motile cells (\%), immotile sperm cells (\%), actual dead sperm count $\left(\times 10^{6} / \mathrm{nl}\right)$, actual live sperm count $\left(\times 10^{6} / \mathrm{nl}\right)$, live sperm $(\%)$, acrosome morphology defects (\%), acrosome detachment $(\%)$, and acrosome swelling (\%) with probability values ranging from 0.003 to 0.783 , whereas minimum progressive motile cells (\%) increase was achieved at an optimum onion and garlic supplementation level of $3.009 \mathrm{~g}$ per $600 \mathrm{~g} \mathrm{DM}$ feed $\left(\mathrm{Y}=4.333+7.300 \mathrm{x}-1.213 \mathrm{x}^{2} ; \mathrm{r}^{2}=0.979 ; \mathrm{P}=0.003\right)$. Several studies have applied the quadratic regression model to optimize inclusion levels of feed materials on farm animals: goats (Ogundun et al., 2013), chicken (Mbajiorgu, 2011; Mbajiorgu et al., 2011; Alabi et al., 2015). However, none of these studies have reported on optimizing the effect of onion and garlic supplemental inclusion levels on sperm quality characteristics of Koekoek breeder cocks. In their studies, Ogundun et al. (2013) reported a single optimum value of $25.57 \%$ of uromalt inclusion level for optimizing average sperm morphology and average sperm abnormality in West African dwarf goats. This is different from the results of the present findings, in which differences in optimum requirements of dietary supplemental inclusion levels of onion and garlic needed to optimize different sperm parametric performances were observed in Koekoek breeder cocks. These differences in optimum supplemental inclusion levels of onion and garlic for optimizing different sperm quality characteristics in Koekoek breeder cocks may have been expected, since feeds of different dietary compositions would give different optimal performance responses (Lin et al., 1980; Buyse et al., 1992; Collin et al., 2003). Thus, this study, which highlights the inclusion of response values of Allium species for optimizing different semen quality parameters, could be dynamic, but trials in which parametric performances were achieved at variable optimal dietary nutrient inclusion levels predominate (Sahin et al., 2002; Mbajiorgu, 2011; Mbajiorgu et al., 2011; Alabi et al., 2015).

In the present study, onion and garlic supplemental inclusion level for optimum sperm count $\left(\times 10^{6} / \mathrm{nl}\right)$ was not reached. It is possible that the onion and garlic supplemental inclusion level required for optimum sperm count $\left(\times 10^{6} / \mathrm{nl}\right)$ in this study was higher than the range of values used in the study. However, results showed that minimum progressive motile cell (\%) increase was achieved at an optimum onion and garlic supplementation level of $3.009 \mathrm{~g}$ per $600 \mathrm{~g} \mathrm{DM}$ feed $\left(\mathrm{Y}=4.333+7.300 \mathrm{x}-1.213 \mathrm{x}^{2} ; \mathrm{r}^{2}=0.979 ; \mathrm{P}=0.003\right)$. This suggests that this inclusion level of $3.009 \mathrm{~g}$ per $600 \mathrm{~g}$ DM feed could ensure production of mature and viable spermatozoa and hence support reproductive efficiency in
Koekoek breeder cocks. Importantly, the sharp increase in progressive motile cell (\%) above this optimum onion and garlic inclusion value of $3.009 \mathrm{~g}$ (Figure 1) tended to indicate that spermatogenic process was affected by this slight detrimental percentage increase in onion and garlic inclusion level and could probably be attributed to high spermicidal effect of the test ingredient as the level of supplementation increases. Thus, it is clear from the results herein that onion and garlic supplemental levels above $3.009 \mathrm{~g}$ per $600 \mathrm{~g}$ DM feed in the diet of Koekoek breeder cocks will decrease progressive motile cell and have important consequences on the quality of the spermatozoa and fertility of Koekoek cocks. These findings have a lot of implications on the use of supplemental onion and garlic inclusion levels to enhance reproductive efficiency in Koekoek breeder cocks.

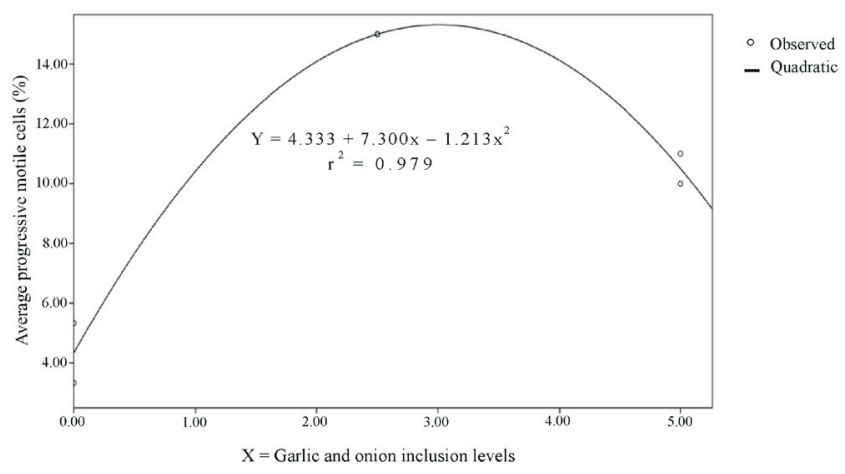

Figure 1 - Effect of optimum inclusion of onion and garlic on progressive motile cells of Koekoek breeder roosters.

\section{Conclusions}

Optimizing onion and garlic inclusion level in the diet of Koekoek breeder cocks will depend on the variable semen quality characteristics, and could be helpful in enhancing their reproductive efficiency.

\section{Acknowledgments}

We wish to acknowledge the funding support by the Department of Animal Science and Technology, Federal University of Technology, Owerri.

\section{References}

Ajayi, F. O.; Agaviezar, B. O. and Ajuogu, K. 2011. Semen characteristics of three strains of local cocks in humid tropical environment of Nigeria. International Journal of Animal Veterinary Advances 3:125-127. 
Alabi, O. J.; Ng'ambi, J. W.; Mbajiorgu, E. F.; Norris, D. and Mabelebele, M. 2015. Growth and haematological response of indigenous Venda chicken aged $8-13$ weeks to varying dietary lysine to energy ratios. Journal of Animal Physiology and Animal Nutrition 99:436-441.

Alagawany, M.; Ashour, E. A. and Reda, F. M. 2015. Effect of dietary supplementation of garlic (Allium sativum) and turmeric (Curcuma longa) on growth performance, carcass traits, blood profile and oxidative status in growing rabbits. Annals of Animal Science. DOI: 10.1515/aoas-2015-0079.

Alkan, S.; Baran, A.; Ozdas, O. B. and Evecen, M. 2002. Morphological defects in turkey semen. Turkish Journal of Veterinary \& Animal Science 26:1087-1092.

Arzanlou, M. and Bohlooli, S. 2010. Introducing of green garlic plant as a new source of allicin. Food Chemistry 120:179-183.

Atmaca, G. 2003. Antioxidative effects of garlic and some thiolcontaining compounds in Turkeys. Trakya Üniversitesi Tip Fakültesi Dergisi 2:54-60.

Barkhordari, A.; Hetmatimoghaddam, S.; Ajebali, M.A.; Khalili, T. A. and Noorani, M. 2013. Effect of Zinc Oxide nanoparticle on viability of human spermatozoa. Iran Journal of Reproductive Medicine 11:767-771.

Buyse, J.; Decuypere, E.; Berghman, L.; Kühn, E. R. and Vandesande, F. 1992. Effect of dietary protein content on episodic growth hormone secretion and on heat production of male broiler chickens. British Poultry Science 33:1101-1109.

Chakrabarti, K.; Pal, S. and Bhattacharyya, A. K. 2003. Sperm immobilization activity of Allium sativa $\mathrm{L}$. and other plant extracts. Asian Journal of Andrology 5:131-136.

Cheng, F. P.; Guo, T. J.; Wu, T. J.; Lin, T. E.; Ursem, P. J. F.; Colenbrander, B. and Fung, H. P. 2002. Annual variation in semen characteristics of pigeons (Columba livia). Poultry Science 81:1050-1056.

Collin, A.; Buyse, J.; van As, P.; Darras, V. M.; Malheiros, R. D.; Moraes, V. M.; Reyns, G. E.; Taouis, M. and Decuypere, E. 2003. Cold-induced enhancement of avian uncoupling protein expression, heat production, and triiodothyronine concentrations in broiler chicks. Genetics \& Comparative Endocrinology 130:70-77.

Durrani, H. Z.; Durrani, A. Z. and Kamal, N. 2010. Comparative efficacy of different therapeutic agents in experimentally induced Leishmaniasis in hamster. Journal of Plant Science 20:13-16.

Egbunike, C. N. and Oluyemi, J. A. 1979. Comparative studies of the reproductive capacity of the Nigerian and exotic poultry breeds. Nigerian Journal of Animal Production 6:47-51.

Elagib, H. A. A.; Musharaf, N. A.; Makawi, S. A. and Mohammed, H. E. 2012. The effects of age and season on semen characteristics of White leghorn cocks under Sudan condition. International Journal of Poultry Science 11:47-49.

Griffiths, G.; Trueman, L.; Crowther, T. and Thomas, B. 2002. Onion a global benefit of health. Phytotherapy Research 17:603-615.

Hafez, B. and Hafez, E. S. E. 2000. Reproduction in farm animals. 7th ed. Lippincoh Williams and Wikkins, USA, New York.

Hassanpour, S.; Sadaghian, M.; MaheriSis, N.; Eshratkhah, B. and ChaichiSemsari, M. 2011. Effect of condensed tannin on controlling faecal protein excretion in nematode-infected sheep: in vivo study. Journal of American Science 7:896-900.

Hunt, C. D.; Johnson, P. E.; Herbel, J. and Mullen, L. K. 1992. Effects of dietary zinc depletion on seminal volume and zinc loss, serum testosterone concentrations, and sperm morphology in young men. American Journal of Clinical Nutrition 56:148-157.

Izawa, H.; Kohara, M.; Aizawa, K.; Suganuma, H.; Inakuma, T.; Watanabe, G.; Taya, K. and Sugai, M. 2008. Alleviative effects of quercetin and onion on male reproductive toxicity induced by diesel exhaust particles. Bioscience Biotechnology Biochemistry $72: 1235-1241$

Kabir, M.; Oni, O. O. and Akpa, G. N. 2007. Osborne selection index and semen traits interrelationships in Rhode Island Red and White breeder cocks. International Journal of Poultry Science 6:999-1002.

Khaki, A.; Fathiazad, F.; Nour, M. and Hamadeh, D. V. M. 2008. Evaluation of androgenic activity of allium cepa on spermatogenesis in the rat. Folia Morphologica 68:44-45.

Khaki, A.; Fathiazard, F.; Nouri, M.; Khaki, A. A.; Khamenehhi, H. J. and Hamadeh, M. 2009. Evaluation of androgenic activity of Allium cepa on spermatogenesis in the rat. Folia Morphologica 68:45-51.

Khaki, A.; Farzadi, L.; Ahmadi, S. and Ghadamkhair, E. 2011. Recovery of spermatogenesis by Allium cepa in Tocoplasma gondii infected rats. African Journal of Pharmacy and Pharmacology 5:903-907.

Khaki, A.; Farnam, A.; Davatgarbadil, A. and Nikniaz, H. 2012. Treatment effects of onion (Allium cepa) and ginger (Zingiber officinale) on sexual behavior of rat after inducing an antiepileptic drug (lamotrigine). Balkan Medical Journal 29:236-242.

Kim, S.; Jo, S.; Kwon, Y. and Hwong, J. 2011. Effect of onion (Allium сера) extract administration on intestinal glucosidases activities and spikes in postprandid blood glucose levels in SD rats model. International Journal Molecular Science 58:213-220.

Lake, P. E. 1957. The male reproductive tract the fowl. Journal of Anatomy 91:116-129.

Lee, B.; Jung J. and Kim, H. 2012. Assessment of red onion on antioxidant activity in rat. Food and Chemical Toxicology 50:3912-3919.

Lin, C. Y.; Friars G. W. and Moran E. T. 1980. Genetic and environmental aspects of obesity in broilers. World's Poultry Science Journal 36:103-111.

Martin, R. D. 2004. Artificial insemination of poultry. Poultry Essays,

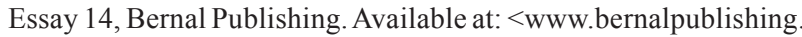
com/poultry/essays/essay1.4shtml>. Accessed on: Dec. 5, 2015.

Mbajiorgu, C. A. 2011. The response of male indigenous Venda chickens to diet energy to protein ratios fed from seven up to 13 weeks of age. Journal of Human Ecology 35:161-166.

Mbajiorgu, C. A.; Ng'ambi J. W. N.; Norris, D. and Alabi O. J. 2011. Effect of dietary lysine to energy ratio on performance of unsexed indigenous Venda chickens. Asian Journal of Animal and Veterinary Advances 6:517-524.

Murugesan, S.; Matam, N.; Kulkarni, R.; Bhattacharya, T. K. and Chatterjee, R. N. 2013. Semen quality in white leghorn chicken select for egg production traits. Turkish Journal of Veterinary and Animal Science 37:747-749.

Ogundun, N. J.; Mbajiorgu, E. F. and Mbajiorgu, C. A. 2013. Dose response effect of percentage Uromalt (M) Inclusion level on Spermatogenesis in West African Dwarf Buck Kids. Indian Journal of Animal Research 47:373-378.

Peters, S. O.; Shoyebo, O. O.; Ilori, B. M.; Ozoje, M. O.; Ikeobi, C. O. N. and Adebambo, O. A. 2008. Semen quality traits of seven strains of chickens raised in the humid tropics. International Journal of Poultry Science 7:949-953.

Riaz, A.; Aleem, M.; Ijaz, A.; Saeed, M. A. and Latiff, A. 2004. Effect of collection frequency on the semen quality of broiler breeders. British Poultry Science 45:823-827.

Saeed, J. M and Al-Soudi, K. A. 1975. Semen quality traits of seven strains of chickens raised in the humid tropics. Animal Verterinary Advances 7:848-849. 
Sahin, K.; Kucuk, O.; Sahin, N. and Gursu, M. F. 2002. Optimal dietary concentration of vitamin $\mathrm{E}$ for alleviating the effect of heat stress on performance, thyroid status, ACTH and some serum metabolite and mineral concentrations in broilers. Veterinari Medicina 47:110-116.

Tarif, A. M.; Bhuiyan, M. M. U.; Ferdousy, R. N.; Juyena, N. S. and Mollah, M. B. R. 2013. Evaluation of semen quality among four chicken lines. IOSR Journal of Agriculture \& Veterinary Science 6:7-13.

Yama, O. E.; Duru, F. I.; Oremosu, A. A.; Osinubi, A. A.; Norohna, C. C. and Okanlawon, A. O. 2011. Sperm quotient in Sprague-Dawley rats fed graded doses of seed extract of Momordica charantia. Middle East Fertility Society Journal 16:154-158. 